\title{
BMJ Open Future health providers' willingness to provide abortion services following decriminalisation of abortion in Chile: a cross-sectional survey
}

\author{
M Antonia Biggs (D , ${ }^{1}$ Lidia Casas, ${ }^{2}$ Alejandra Ramm, ${ }^{3,4}$ C Finley Baba, ${ }^{1}$ \\ Sara Victoria Correa, ${ }^{3}$ Daniel Grossman ${ }^{1}$
}

To cite: Biggs MA, Casas L, Ramm A, et al. Future health providers' willingness to provide abortion services following decriminalisation of abortion in Chile: a crosssectional survey. BMJ Open 2019;9:e030797. doi:10.1136/ bmjopen-2019-030797

- Prepublication history for this paper is available online. To view these files, please visit the journal online (http://dx.doi. org/10.1136/bmjopen-2019030797).

Received 02 April 2019 Revised 28 June 2019 Accepted 08 October 2019

Check for updates

(c) Author(s) (or their employer(s)) 2019. Re-use permitted under CC BY-NC. No commercial re-use. See rights and permissions. Published by BMJ.

${ }^{1}$ Advancing New Standards in Reproductive Health, Department of Obstetrics, Gynecology, and Reproductive Sciences, University of California, San Francisco, Oakland, California, USA

${ }^{2}$ Centro de Derechos Humanos, Facultad de Derecho, Universidad Diego Portales, Santiago, Chile

${ }^{3}$ Instituto de Investigacion en Ciencias Sociales, Universidad Diego Portales, Santiago, Chile

${ }^{4}$ Escuela de Sociología, Universidad de Valparaíso, Valparaíso, Chile

Correspondence to Dr M Antonia Biggs; antonia.biggs@ucsf.edu

\section{ABSTRACT}

Objective To assess Chilean medical and midwifery students' attitudes and willingness to become trained to provide abortion care, shortly after abortion was decriminalised in 2017.

Design We fielded a cross-sectional, web-based survey of medical and midwifery students. We used generalised estimating equations to assess differences by type of university and degree sought.

Setting We recruited students from a combination of seven secular, religiously-affiliated, public and private universities that offer midwifery or medical degrees with a specialisation in obstetrics and gynaecology, located in Santiago, Chile.

Participants Students seeking medical or midwifery degrees at one of seven universities were eligible to participate. We distributed the survey link to medical and midwifery students at these seven universities; 459 eligible students opened the survey link and 377 students completed the survey.

Primary and secondary outcomes Intentions to become trained to provide abortion services was our primary outcome of interest. Secondary outcomes included moral views and concerns about abortion provision.

Results Most students intend to become trained to provide abortion services (69\%), 20\% reported that they will not provide an abortion under any circumstance, half $(50 \%)$ had one or more concern about abortion provision and $16 \%$ agreed/strongly agreed that providing abortions is morally wrong. Most believed that their university should train medical and midwifery students to provide abortion services $(70 \%-79 \%)$. Secular university students reported higher intentions to provide abortion services (beta 0.47 , $95 \% \mathrm{Cl}: 0.31$ to 0.63 ), more favourable views (beta 0.52 , $\mathrm{Cl} 0.32$ to 0.72 ) and were less likley to report concerns about abortion provision (adjusted OR $0.47, \mathrm{Cl}: 0.23$ to $0.95)$ than students from religious universities.

Conclusion Medical and midwifery students are interested in becoming trained to provide abortion services and believe their university should provide this training. Integrating high-quality training in abortion care into medical and midwifery programmes will be critical to ensuring that women receive timely, non-judgemental and quality abortion care.

\section{Strengths and limitations of this study}

- This is the first study to assess Chilean medical and midwifery students' willingness and concerns about providing abortion services soon after Chile lifted its complete ban on abortion.

- This study recruited students from a range of universities including secular, religious, public and private universities.

- This study includes important explanatory variables including political affiliation, religion, frequency of attendance at religious services and year in medical or midwifery school, allowing us to identify whether any of these variables are associated with our outcomes.

- Our response rate was low and students from religious universities were under-represented raising some concerns of response bias.

- We did not ask students the circumstances under which they would consider providing abortion services, whether they were aware about the change in the law or the circumstances in which abortion has currently been decriminalised.

\section{INTRODUCTION}

In August 2017, Chile's constitutional tribunal approved allowing abortion when a woman's life is in danger, lethal fetal anomaly and for pregnancies due to rape. In the 1990s, when abortion was completely banned, abortion providers consisted of a mix of trained and untrained providers, many of whom had low levels of education and literacy, resulting in high rates of maternal mortality due to abortion. ${ }^{1}$ During that period, healthcare providers reported a fear of prosecution when treating women with fetal or maternal complications, ${ }^{2}$ and healthcare providers and hospitals filed the majority of cases against women who had abortions. ${ }^{3}$ Since the 1990 s to early 2000s, maternal mortality due to abortion has decreased considerably, ${ }^{4}$ owing 
to increased access to contraception, misoprostol and higher quality postabortion care. ${ }^{25}$

Under the current law, only physicians are authorised to provide abortions and any individual directly involved in the abortion procedure, and institutions are permitted to claim conscientious objection refusals. However, objecting providers are required to refer people interested in abortion to a willing provider and to care for patientswith postabortion complications. It is legally required that everyone seeking abortion be given oral and written information about alternatives to abortion, information about social and financial support programmes and be offered accompaniment (psychological and emotional support) services, before and after the abortion. ${ }^{6}$ Soon after legal reform, the Ministry of Health provided resources to clinicians informing them about the requirements around conscientious objection, as well as guidelines around how to provide psychological and emotional support to people seeking abortion. ${ }^{7}$ The Ministry of Health also provided a brief list of clinical fetal and maternal indications that allow a woman to obtain an abortion on maternal and fetal health grounds. While the Ministry of Health has provided abortion training to providers throughout the country, it has not disseminated any specific clinical guidelines around abortion provision. Since the first full year of implementation of the law, there have been over 600 legal abortions in the country, the greatest proportion of which are for maternal indications $(45 \%)$, followed by fetal conditions $(40 \%)$ and rape $(15 \%){ }^{68}$

A few studies have examined future providers' attitudes and willingness to provide abortion in places where abortion has recently been liberalised or abortion is highly restricted. In Ghana, a survey of final year midwifery students found that, following abortion liberalisation, the majority $(70 \%)$ reported that they were somewhat or very likely to provide abortion services once they had graduated. ${ }^{9}$ The most common reasons for being unwilling to provide services were personal and religious beliefs. Shortly after legal reform in Colombia, a majority of medical students $(>90 \%)$ surveyed supported abortion decriminalisation under the current law, yet few felt prepared to offer abortion care. ${ }^{10}$ In Ethiopia, a survey of female higher education students, found that only a minority were aware of the circumstances in which abortion had been recently legalised. ${ }^{11}$ In India, medical students also reported a lack of knowledge about and fear of providing abortion services. ${ }^{12}$

Legal reform introduces a new challenge and opportunity for prospective health care providers. They must now consider whether or not they are willing to develop their skills to fill a critical service gap in an environment that lacks experienced clinicians and has limited capacity to provide abortion services. The extent to which future providers welcome, reject and/or are concerned about providing abortion-related care, now that abortion is legally permissible in Chile, is unclear. This study aims to deepen our understanding of medical and midwifery students' attitudes, concerns and willingness to provide abortion-related care, a critical step in identifying the country's future abortion training needs.

\section{MATERIALS AND METHODS \\ Study design}

We conducted a cross-sectional survey of prospective health care providers seeking medical or midwifery degrees at universities located in the metropolitan region of Santiago, Chile's capital. We powered our sample to detect mean differences in abortion attitudes by university type (secular vs religious university) and degree type (medical vs midwifery). We estimated that a sample of 300 , with a minimum group size of 90 , could detect a mean difference of 0.45 , on a 4-point scale, and as reported in a published abortion stigma subscale, with an SD of 1.07 and a two-sided alpha of $5 \%$ and $80 \%$ power. ${ }^{13}$

\section{Recruitment procedures}

We selected a combination of seven secular, religious, public, and private universities that offer midwifery or medical degrees with a specialisation in obstetrics and gynaecology, located in Santiago, Chile, to serve as recruitment sites. This included seven medical and five midwifery departments within these seven universities. In Chile, a degree in medicine usually requires 7 years of study; midwifery programmes are typically 5-year programmes that train students in obstetrics, perinatal health and neonatology. Midwifery programmes are usually located within a university's school of medicine, nursing or health sciences, but midwifery is considered a completely separate career from medicine or nursing. Based on a review of the Ministry of Education and university websites, we estimated that the seven participating universities serve over 7000 students seeking medical or midwifery degrees, representing $72 \%$ of medical and $38 \%$ of midwifery students in the metropolitan region of Santiago and $36 \%$ of medical and $16 \%$ of midwifery students in the country. ${ }^{14}$ Among the 7026 medical and midwifery students in our student pool at these seven universities, $65 \%$ are at secular universities, $35 \%$ are at religious universities, $80 \%$ are medical students and $20 \%$ are midwifery students.

We requested department administrators and student leaders to distribute a survey link to their medical and midwifery students. Six departments at four universities shared the link with students directly through student listservs or department Facebook pages. At the two nonresponding universities, we distributed paper flyers that included the survey link and a QR code to medical and midwifery students. Interested participants were entered into a gift card drawing (worth US $\$ 40 /$ CLP $\$ 24000$ ) of 25 randomly selected winners.

\section{Survey administration}

We fielded a web-based, anonymous survey from October 2017 to May 2018. Students seeking a medical or midwifery 
degree at one of the seven identified universities were eligible to participate. Interested students reviewed an online consent form, consented and completed the survey. The survey assessed students' moral views, ${ }^{15}$ intentions ${ }^{16}$ and concerns about providing abortion. ${ }^{17}$ We drew items from the published literature ${ }^{15-17}$ and adapted them to be applicable to university students and in a context in which provision of abortion had not been previously legal. The final survey tool was then pilot tested with six students before distributing it to the full sample.

\section{Patient and public involvement}

Prior to developing the student survey, we conducted 30 in-depth qualitative in-person interviews with clinical teaching faculty at the same seven universities where we intended to survey students and within the schools' obstetrics/gynaecology (OB/GYN) and midwifery departments. Findings from the faculty interviews informed the development of the research questions and the development of the student survey. Before finalising the survey, we shared an initial draft of survey items with faculty members teaching in the fields of obstetrics, gynaecology, medical ethics and midwifery and with the study team for review and comment. We have presented a summary of the findings at several medical and midwifery schools and among reproductive health professionals in Chile and plan to continue presenting the results at professional conferences. We did not include patient involvement in the design of this study.

\section{Outcome variables}

Drawing from the literature of abortion attitudes and intentions to provide abortion, we identified three abortion provision domains. We examined five outcomes related to the three abortion provision domains. We tested the internal consistency reliability of each domain and confirmed that each of the three domains produced acceptable Cronbach's alpha scores. We derived the concerns about abortion provision items from a US survey of students enrolled in a health sciences programme (ie, medicine, nursing, etc).${ }^{17}$ Items included: "Now that abortion is legal in certain circumstances, to what extent do the following factors related to abortion provision concern you?" Followed by seven, Likert-scaled (1strongly disagree to 5-strongly agree) items: "It is against my personal values"; "I fear that I would have legal problems"; "It is against my religious beliefs"; "It is outside my scope of practice"; "I fear that either I or my family may be harassed and/or threatened by others"; "I may be ostracized by my colleagues and/or discriminated against in my profession" and "I fear being rejected by my family or friends". Average scores across items served as our continuous concerns about abortion provision outcome. Having one or more concern served as a dichotomous outcome which included anyone who agreed or strongly agreed with any of these seven items. We adapted moral views about abortion provision items from a survey instrument developed among clinicians in Ghana. ${ }^{18}$ Items included respondents' level of agreement (1-strongly disagree to 5-strongly agree) with five items: "The needs of a patient are more important than the beliefs of a clinician"; "Abortion should be covered as part of public health services"; "Providing abortions is a positive contribution to society"; "Clinicians have a responsibility to counsel patients against having an abortion" and "I feel that providing abortions is morally wrong". After reverse coding the latter two items, average scores across items served as a continuous morally favourable views about abortion provision outcome. For intentions to provide abortion services items were derived from a survey developed for use among medical students in South Africa. ${ }^{16}$ Participants were asked: "Now that abortion is legal in some circumstances, how do you think this will affect your future practice?", and to indicate their level of agreement (1—strongly disagree to 4-strongly agree) with four items: "I intend to become trained to provide abortion services"; "I will try to convince other doctors to provide abortions"; "If a female patient requested an abortion, I would try to discourage her from seeking the procedure" and "I will not provide an abortion under any circumstance." After reverse coding the latter two items, average scores served as one continuous outcome. Endorsement (agreed/strongly agreed) of I plan to become trained to provide abortion services served as final dichotomous outcome.

\section{Independent variables}

Independent variables included university type (secular or religious), gender, age group, degree type (medicine-undecided specialty, medicine-obstetrics and gynaecology specialty and midwifery), political affiliation (none/centre, right/centre right and left/centre left), religion (Catholic or other religion vs none/ atheist/agnostic), frequency of attendance to religions services, year in medical/midwifery school, region where student completed high school (Santiago vs other) and as a proxy for socioeconomic status, type of high school attended (public, private-subsidised and private-self-paid).

\section{Analyses}

We estimated frequencies for participant and university characteristics (table 1) and each abortion provision domain. We present students' views about whether their university should train medical and midwifery students on abortion provision in table 2 and internal consistency Cronbach's alpha reliability coefficients for each outcome domain in table 3. For multivariable models, we used linear and logistic general estimating equation models accounting for clustering by university (tables 4 and 5). To test associations between participant characteristics and our main outcomes, we selected model covariates known to be associated with abortion attitudes based on the existing literature. ${ }^{19}$ We conducted all analyses in STATA V.14. Significance was reported at $\mathrm{p} \leq 0.05$. 


\begin{tabular}{|c|c|c|}
\hline & $\mathbf{N}$ & $\%$ \\
\hline \multicolumn{3}{|l|}{ Gender } \\
\hline Female & 239 & 64 \\
\hline Male & 136 & 36 \\
\hline Other & 1 & $<1$ \\
\hline \multicolumn{3}{|l|}{ Age group } \\
\hline $17-19$ & 95 & 25 \\
\hline $20-24$ & 222 & 59 \\
\hline $25-37$ & 60 & 16 \\
\hline Attends secular university & 292 & 77 \\
\hline Attends private university & 262 & 63 \\
\hline \multicolumn{3}{|l|}{ Degree pursuit } \\
\hline Midwifery/Obstetrics & 94 & 25 \\
\hline Medicine-undecided specialty & 186 & 49 \\
\hline $\begin{array}{l}\text { Medicine-obstetrics/ } \\
\text { gynaecology specialty }\end{array}$ & 97 & 26 \\
\hline \multicolumn{3}{|l|}{ University year } \\
\hline First to second & 163 & 43 \\
\hline Third to fourth & 127 & 34 \\
\hline Fifth to sixth & 47 & 12 \\
\hline Last year/Just graduated & 40 & 11 \\
\hline Born in Chile & 368 & 98 \\
\hline
\end{tabular}

\begin{tabular}{|lrr|}
\hline Santiago metropolitan region & 285 & 76 \\
\hline Northern Chile & 34 & 9 \\
\hline Southern Chile & 54 & 14 \\
\hline Other country & 4 & 1 \\
\hline Not married & 369 & 98 \\
\hline Political affiliation & & \\
\hline Right/centre right & 95 & 25 \\
\hline Centre & 32 & 8 \\
\hline Centre left/left & 171 & 45 \\
\hline None & 79 & 21 \\
\hline
\end{tabular}

Frequency of religious attendance

\begin{tabular}{lrr}
$\begin{array}{l}\text { Once a week/two to three times } \\
\text { a month }\end{array}$ & 43 & 12 \\
$\begin{array}{l}\text { Once a month/two to three times } \\
\text { a year }\end{array}$ & 64 & 17 \\
$\begin{array}{l}\text { Hardly ever/never } \\
\text { Religion }\end{array}$ & 270 & 72 \\
\hline $\begin{array}{l}\text { Catholic } \\
\text { Evangelical/protestant }\end{array}$ & 143 & 38 \\
\hline $\begin{array}{l}\text { Other } \\
\text { None/atheist/agnostic }\end{array}$ & 16 & 4 \\
\hline $\begin{array}{l}\text { Lived 1 year or more outside of } \\
\text { Chile }\end{array}$ & 202 & 4 \\
\hline
\end{tabular}

Continued
Table 1 Continued

N $\%$

Type of high school attended

\begin{tabular}{lrr} 
Public & 73 & 19 \\
Private (subsidised) & 140 & 37 \\
Private (self-paid) & 164 & 44 \\
\hline
\end{tabular}

\section{RESULTS}

\section{Respondent characteristics}

The survey link was distributed to an estimated 2148 medical and midwifery students and 459 opened the survey link; we removed 46 surveys due to ineligibility and 36 surveys that were less than $40 \%$ complete or were missing outcome data, leaving a final sample of 377 . There were no statistically significant differences by gender, religion, age, year in school, university type, type of degree being pursued or political affiliation between our final sample $(n=377)$ and those with incomplete surveys $(n=36)$. We describe student and university characteristics in table 1. Most students attended a secular university $(77 \%), 63 \%$ a private university and $75 \%$ were seeking a medical degree (49\% undecided specialty and $26 \%$ with specialisation in obstetrics and gynaecology). Most students felt that their university should provide abortion training to all medical students $(70 \%)$, medical students with an $\mathrm{OB} / \mathrm{GYN}$ specialty $(79 \%)$ and to midwifery students $(78 \%$, table 2$)$. After removing all observations with missing outcome data, there were no missing data for any of the independent variables of interest. However, there were 68 missing responses for the question asking students if their university should provide abortion training to their students.

\section{Concerns, moral views and intentions to provide abortion- related services}

Half $(50 \%)$ of students agreed/strongly agreed that they had one or more concern about providing abortionrelated services. Primary concerns included: providing abortion was against their personal values $(32 \%)$ or religious beliefs $(18 \%)$ and a fear of legal problems (23\%; table 3). Overall concerns about providing abortionrelated services were significantly higher among students attending religious than those attending secular universities (mean 2.59 vs $1.84, \mathrm{p}<0.05$ ), with no statistically significant differences by the type of degree being pursued.

Over three quarters $(77 \%)$ of students agreed/strongly agreed that the needs of a patient are more important than the beliefs of a clinician, $61 \%$ agreed that abortion should be covered as part of public health services, $57 \%$ agreed that providing abortions is a positive contribution to society and $16 \%$ agreed that providing abortions is morally wrong (table 3). Students from secular universities were significantly more likely to hold morally favourable views about abortion provision than students from religious universities (mean 3.97 vs $2.92, \mathrm{p}<0.05$ ), with no statistically significant differences by type of degree being pursued. 
Table 2 Student views about whether their university should train medical and midwifery students on abortion provision, $\mathrm{n}=309$

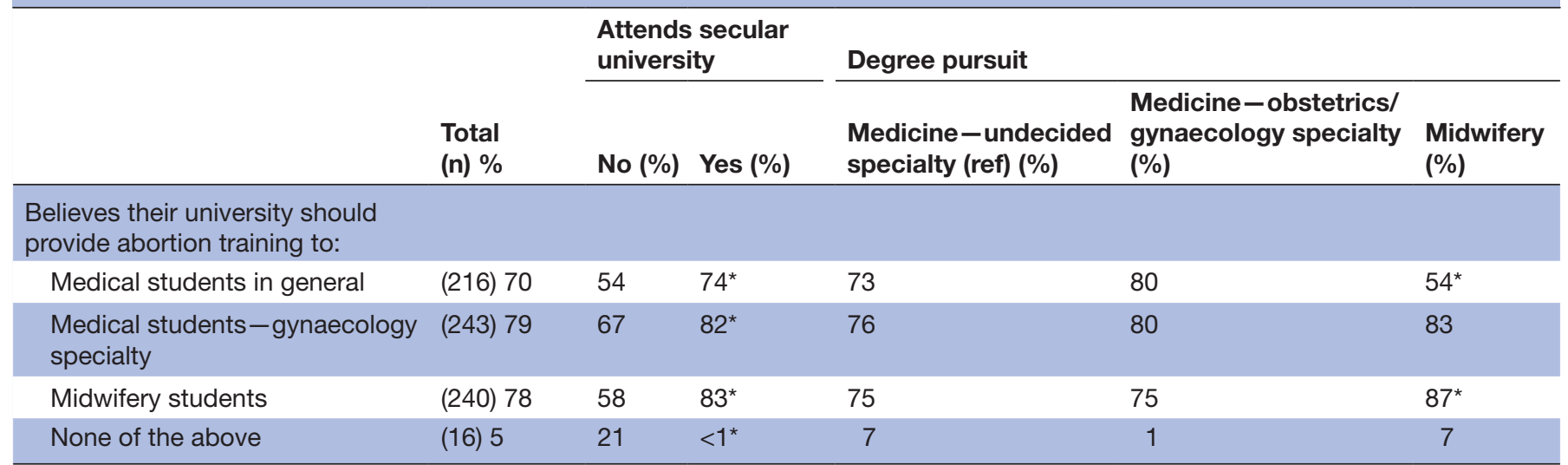

${ }^{*} \mathrm{P}<0.05$, based on mixed effect logistic regression analyses accounting for clustering by university. There were 68 missing responses to the question on whether their university should provide abortion training to their students. ref, referent group.

Nearly two-thirds $(69 \%)$ of students agreed/strongly agreed that they plan to become trained to provide abortion services, but only $21 \%$ would try to convince other doctors to provide abortion services. Approximately one in five students agreed that they would discourage a woman from seeking an abortion $(21 \%)$ and that they will not provide an abortion under any circumstance $(20 \%)$. Students from secular universities had significantly higher overall intentions to provide abortion-related services than students from religious universities (mean 2.99 vs 2.11, $\mathrm{p}<0.05$ ). Medical students specialising in obstetrics and gynaecology $(24 \%)$ were significantly $(\mathrm{p}<0.05)$ more likely than medical students who had not yet decided on their specialty $(10 \%)$ to agree that they would try to discourage a patient from seeking an abortion. Midwifery students $(11 \%)$ were less likely than medical students with an undecided specialty (24\%) to say they would try to convince other doctors to provide abortions.

In multivariable analyses, factors associated with having one or more concern about abortion provision included having a right/centre right political affiliation (adjusted OR (aOR) 2.96, CI: 1.42 to 6.19 ) and attending religious services three times a month or more (aOR 5.14, CI: 1.73 to 15.26; table 4). Factors associated with lower odds of having concerns about abortion provision included attending a secular university (aOR 0.47; CI: 0.23 to 0.95 ) and identifying as atheist, agnostic or of no religion (aOR 0.47 , CI: 0.23 to 0.95 ).

Factors associated with having morally favourable views about abortion provision included attending a secular university (beta 0.52 , CI: 0.32 to 0.72 ), being female (beta 0.21, CI: 0.05 to 0.37 ), having completed their high school education in Santiago (beta 0.19, CI: 0.02 to 0.36 ), identifying as left/centre left political affiliation (beta 0.23 , CI: 0.05 to 0.41 ) and being in the last few years of medical/ midwifery school (beta 0.34 , CI: 0.09 to 0.58 ; table 4 ). Those who identified as right/centre right political affiliation (beta -0.52 , CI: -0.72 to 0.31 ) or attended religious services frequently (beta -0.91 , CI: -1.16 to 0.65 ) were less likely to hold morally favourable views about abortion provision.

Factors associated with overall intentions to provide abortion services and specifically having plans to get trained to provide abortion services included attending a secular university (beta 0.47 , CI: 0.31 to 0.63 and aOR 2.74, CI: 1.38 to 5.43 , respectively), having a left/centre left political affiliation (beta 0.20 , CI: 0.06 to 0.34 and aOR 2.22, CI: 1.01 to 4.07 ) and being in the third or fourth year in medical/midwifery school (beta 0.17 , CI: 0.02 to 0.33 and aOR 2.48, CI: 1.09 to 5.28 ; table 5). Identifying as atheist, agnostic or of no religion was associated with higher overall intentions to provide abortion services (beta 0.24, CI: 0.09 to 0.39). Factors associated with fewer overall intentions and plans to become trained to provide abortion services included having a right/centre right political affiliation (beta -0.42 , CI: -0.58 to 0.26 and aOR 0.45 , CI: 0.22 to 0.90 ) and attending religious services frequently (beta -0.60 , CI: -0.80 to 0.40 and aOR 0.16 , CI: 0.06 to 0.41 ). Students ages 25 and older had signficantly lower odds of intending to become trained to provide abortion services than those ages 20-24 (aOR 0.35, CI: 0.14 to 0.87 ).

\section{DISCUSSION}

Findings from this study highlight widespread support among prospective clinicians to build a qualified workforce to provide abortion services under the current law in Chile. The vast majority of secular and over one-third of religiously- affiliated university students have intentions to become trained to provide abortion services. Moreover, only 1 in 10 secular university students and less than half of students at religious universities said they will not provide abortion services under any circumstance. Most students, even those at religious universities, felt that they should receive abortion-related training and 
Table 3 Student attitudes, concerns and intentions to become trained to provide abortion services

\begin{tabular}{|c|c|c|c|c|c|c|}
\hline & \multirow[b]{2}{*}{ Total } & \multicolumn{2}{|c|}{$\begin{array}{l}\text { Attends secular } \\
\text { university }\end{array}$} & \multicolumn{3}{|l|}{ Degree pursuit } \\
\hline & & No & Yes & $\begin{array}{l}\text { Medicine- } \\
\text { undecided } \\
\text { specialty-ref }\end{array}$ & $\begin{array}{l}\text { Medicine- } \\
\text { obstetrics/ } \\
\text { gynaecology } \\
\text { specialty }\end{array}$ & Midwifery \\
\hline \multicolumn{7}{|l|}{ Concerns about providing abortion services, $n=377$} \\
\hline It is against my personal values & 32 & 62 & $23^{*}$ & 28 & 31 & 39 \\
\hline I fear that I would have legal problems & 23 & 33 & $20^{*}$ & 20 & 25 & 29 \\
\hline It is against my religious beliefs & 18 & 42 & $11^{*}$ & 16 & 18 & 22 \\
\hline It is outside of my scope of practice & 15 & 45 & $7^{*}$ & 14 & 8 & 25 \\
\hline I fear of being rejected by my family or friends & 7 & 8 & 7 & 6 & 9 & 7 \\
\hline Has at least one or more concern & 50 & 76 & $42^{*}$ & 44 & 51 & 60 \\
\hline \multicolumn{7}{|l|}{ Moral views about abortion provision, $n=344$} \\
\hline $\begin{array}{l}\text { Overall moral views scale }(1-5) \text {, alpha }=0.85 \text {, mean } \\
\text { (SD) }\end{array}$ & $3.74(1.0)$ & $2.92(1.0)$ & $3.97(0.8)^{\star}$ & $3.78(0.9)$ & $3.84(0.9)$ & $3.55(1.1)$ \\
\hline \multicolumn{7}{|l|}{ Percent strongly agree/agree: } \\
\hline $\begin{array}{l}\text { The needs of a patient are more important than the } \\
\text { beliefs of a clinician }\end{array}$ & 77 & 51 & $84^{*}$ & 76 & 79 & 76 \\
\hline $\begin{array}{l}\text { Abortion should be covered as part of public health } \\
\text { services }\end{array}$ & 61 & 30 & $70^{*}$ & 63 & 68 & 51 \\
\hline \multicolumn{7}{|l|}{ Percent strongly agree/agree: } \\
\hline $\begin{array}{l}\text { I intend to become trained to provide abortion } \\
\text { services }\end{array}$ & 69 & 38 & $78^{*}$ & 71 & 70 & 63 \\
\hline $\begin{array}{l}\text { I would try to discourage a patient from seeking } \\
\text { abortion-R }\end{array}$ & 21 & 51 & $13^{*}$ & 16 & $24^{*}$ & 29 \\
\hline $\begin{array}{l}\text { I will try to convince other doctors to provide } \\
\text { abortions }\end{array}$ & 21 & 8 & $25^{*}$ & 24 & 26 & $11^{*}$ \\
\hline $\begin{array}{l}\text { I will not provide abortions under any } \\
\text { circumstances }-\mathrm{R}\end{array}$ & 20 & 47 & $13^{*}$ & 18 & 14 & 31 \\
\hline
\end{tabular}

${ }^{*} \mathrm{p}<.05$ based on unadjusted analyses.

$\mathrm{R}$, reverse coded; ref, referent group.

moral opposition to abortion was low. Religious university students' desire to receive abortion training is in conflict with the position that some religious universities have taken-to claim institutional-level refusals to provide abortion care at their hospitals. ${ }^{20} 21$

More than half $(57 \%)$ of students believe providing abortion services is a positive contribution to society and few $(16 \%)$ thought that providing abortions is morally wrong. Holding morally favourable views about abortion provision was higher among students who were further along in their medical and midwifery training suggesting that experience may impact students' willingness to provide such services. Studies in Poland, Ghana and South Africa, similarly have found that medical and midwifery students' in their later years of study had more favourable attitudes about abortion, abortion provision and were more willing to provide abortion services than students in the first few years of study. ${ }^{9} 1622$ Study participants' 
Table 4 Factors associated with concerns and moral views about providing abortion-related services, according to multivariable regression analyses

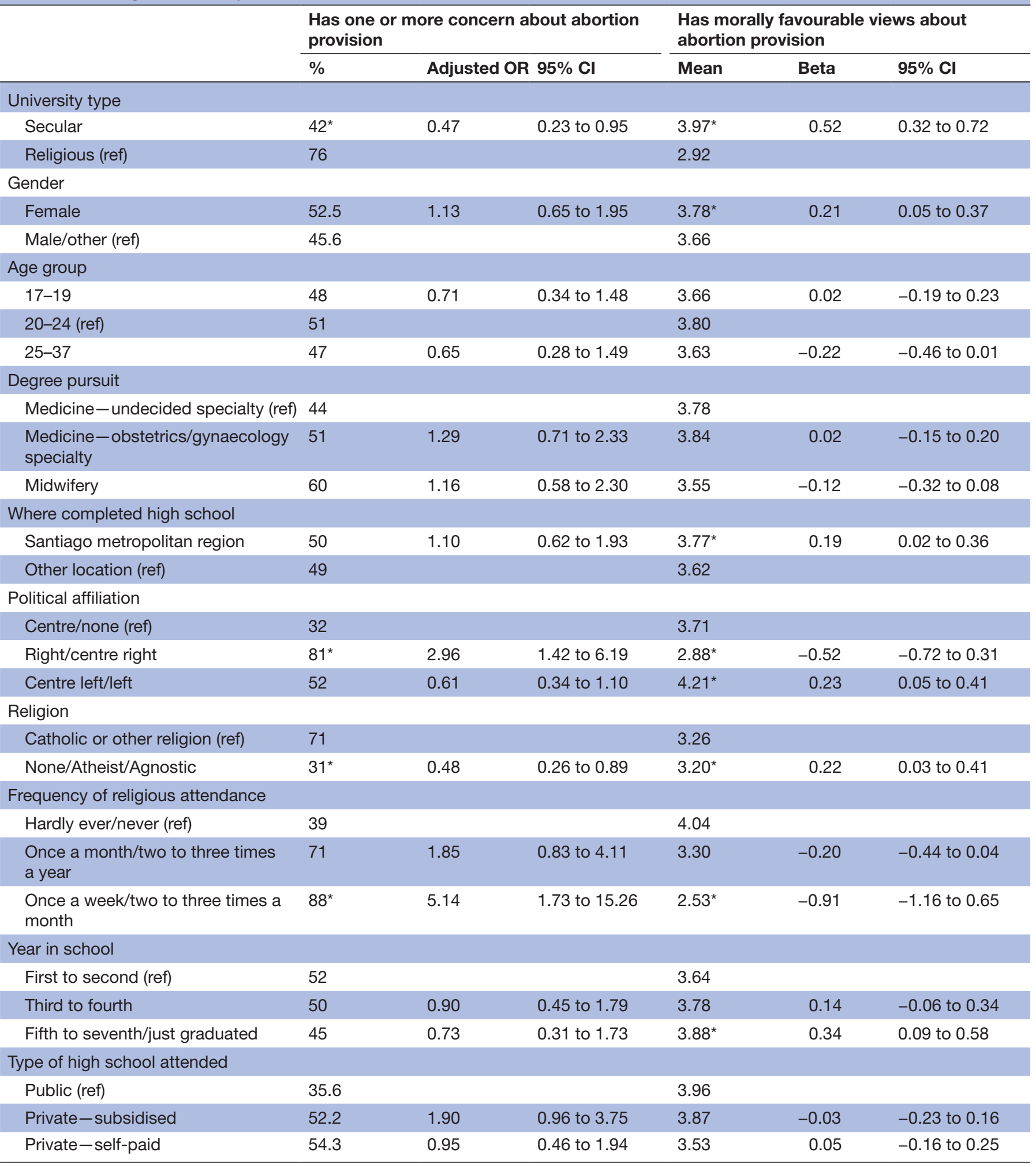

${ }^{*} \mathrm{P}<0.05$.

aOR, adjusted OR; ref, referent group.

views and intentions to become trained to provide abortion services are likely to change even further once they become practising clinicians, as organisational barriers and stigma may deter interested clinicians from abortion provision. ${ }^{23} 24$ 
Table 5 Factors associated with intentions to become trained to provide abortion services, according to multivariable linear and logistic regression analyses

\begin{tabular}{|c|c|c|c|c|c|c|}
\hline & \multicolumn{3}{|c|}{$\begin{array}{l}\text { Intentions to provide abortion services } \\
\text { scale }\end{array}$} & \multicolumn{3}{|c|}{$\begin{array}{l}\text { Intends to become trained to provide } \\
\text { abortion services }\end{array}$} \\
\hline & Mean & Beta & $95 \% \mathrm{Cl}$ & $\%$ & aOR & $95 \% \mathrm{Cl}$ \\
\hline \multicolumn{7}{|l|}{ University type } \\
\hline Secular & $2.99^{\star}$ & 0.47 & 0.31 to 0.63 & $78^{*}$ & 2.74 & 1.38 to 5.43 \\
\hline Religious (ref) & 2.11 & & & 38 & & \\
\hline \multicolumn{7}{|l|}{ Gender } \\
\hline Female & 2.80 & 0.09 & -0.04 to 0.21 & 70 & 1.64 & 0.88 to 3.05 \\
\hline Male/other (ref) & 2.78 & & & 66 & & \\
\hline \multicolumn{7}{|l|}{ Age group } \\
\hline $17-19$ & 2.75 & 0.05 & -0.11 to 0.22 & 67 & 1.30 & 0.59 to 2.88 \\
\hline 20-24 (ref) & 2.87 & & & 73 & & \\
\hline $25-37$ & $2.58^{*}$ & -0.29 & -0.47 to 0.10 & $53^{*}$ & 0.35 & 0.14 to 0.87 \\
\hline \multicolumn{7}{|l|}{ Degree pursuit } \\
\hline $\begin{array}{l}\text { Medicine-undecided specialty } \\
\text { (ref) }\end{array}$ & 2.85 & & & 71 & & \\
\hline $\begin{array}{l}\text { Medicine-obstetrics/ } \\
\text { gynaecology specialty }\end{array}$ & 2.86 & -0.01 & -0.15 to 0.12 & 70 & 0.96 & 0.48 to 1.90 \\
\hline Midwifery & 2.61 & -0.10 & -0.26 to 0.06 & 63 & 0.80 & 0.36 to 1.79 \\
\hline \multicolumn{7}{|l|}{ Where completed high school } \\
\hline Santiago metropolitan region & 2.80 & 0.06 & -0.06 to 0.19 & 69 & 1.14 & 0.61 to 2.16 \\
\hline Other location (ref) & 2.77 & & & 67 & & \\
\hline \multicolumn{7}{|l|}{ Political affiliation } \\
\hline Centre/none (ref) & 2.77 & & & 68 & & \\
\hline Right/centre right & $2.10^{*}$ & -0.42 & -0.58 to 0.26 & $37^{*}$ & 0.45 & 0.22 to 0.90 \\
\hline Centre left/left & 3.20 & 0.20 & 0.06 to 0.34 & $87^{*}$ & 2.22 & 1.01 to 4.07 \\
\hline \multicolumn{7}{|l|}{ Religion } \\
\hline Catholic or other religion (ref) & 2.39 & & & 51 & & \\
\hline None/Atheist/Agnostic & $3.14^{*}$ & 0.24 & 0.09 to 0.39 & 84 & 1.49 & 0.74 to 3.01 \\
\hline \multicolumn{7}{|l|}{ Frequency of religious attendance } \\
\hline Hardly ever/never (ref) & 3.03 & & & 80 & & \\
\hline $\begin{array}{l}\text { Once a month/two to three times } \\
\text { a year }\end{array}$ & 2.43 & -0.13 & -0.31 to 0.06 & 50 & 0.49 & 0.21 to 1.12 \\
\hline $\begin{array}{l}\text { Once a week/two to threetimes a } \\
\text { month }\end{array}$ & $1.88^{\star}$ & -0.60 & -0.80 to 0.40 & $26^{*}$ & 0.16 & 0.06 to 0.41 \\
\hline \multicolumn{7}{|l|}{ Year in school } \\
\hline First to second year (ref) & 2.71 & & & 65 & & \\
\hline Third to fourth year & $2.90^{*}$ & 0.17 & 0.02 to 0.33 & $76^{*}$ & 2.48 & 1.09 to 5.28 \\
\hline $\begin{array}{l}\text { Fifth to seventh year/just } \\
\text { graduated }\end{array}$ & $2.81^{*}$ & 0.26 & 0.06 to 0.46 & 64 & 2.18 & 0.78 to 6.13 \\
\hline \multicolumn{7}{|l|}{ Type of high school attended } \\
\hline Public (ref) & 2.95 & & & 84 & & \\
\hline Private-subsidised & 2.88 & 0.00 & -0.15 to 0.15 & $70^{*}$ & 0.37 & 0.13 to 0.82 \\
\hline Private-self-paid & 2.65 & 0.12 & -0.04 to 0.27 & 61 & 0.64 & 0.26 to 1.55 \\
\hline
\end{tabular}

${ }^{*} \mathrm{P}<0.05$.

aOR, adjusted OR; ref, referent group. 
Along with the high level of support and intentions to become trained to provide abortion services, over half of students held concerns, mainly related to their personal values and religious beliefs and also due to a fear of legal problems and of being harassed or threatened. These concerns may be well founded, as evidenced by the public defaming of the physician who performed the first legal abortion in the country. ${ }^{25}$ Furthermore, the broad adoption of conscientious objector status among clinicians and institutions ${ }^{26}$ may be a product of and/or contributor to the stigma of being an abortion provider. Clinicians in Chile may require extensive support professionally to ensure that they feel safe providing abortion services to to their patients. Access to training programmes to help reduce provider stigma around abortion, as well as burnout, such as that offered by the Provider Share Workshop, is one example of how a future abortion care workforce could be supported. ${ }^{27}$

Consistent with numerous studies documenting the relationship between political views, religiosity and abortion attitudes among medical students, clinicians and the general public, ${ }^{28-30}$ we found that students' political affiliation and frequency of religious attendance was strongly associated with students' moral views and willingness to become trained to provide abortion services. Students' religious beliefs are likely to influence their clinical opinions and interactions, and thus they may benefit from training to ensure that they are able to provide non-judgemental services. Studies in the USA have found that OB/GYN residents who were morally opposed to abortion but partially participated in an abortion training programme felt they gained important clinical and professional skills from the abortion training. ${ }^{31} 32$

While there was widespread interest in learning to provide abortion-related services among medical and midwifery students attending religious institutions, it is unlikely that these institutions will train their students to provide abortion procedures. Furthermore, while most midwifery students reported interest in becoming trained to provide abortion care, they currently are prohibited from performing procedures. However, there is a wide range of abortion-related information and skills that arguably should be offered as part of any medical or midwifery student curriculum, irrespective of their religious affiliation or prohibition on abortion provision. Medical and midwifery schools could train students to give accurate, informed and non-judgemental pregnancy options counselling and referrals for abortion care, ${ }^{33}$ to provide high-quality postabortion care, including managing complications and miscarriage management, ${ }^{34}$ to develop competencies on how to address specificpatient scenarios related to abortion care, and to offer offsite residency abortion training programmes. The extent to which medical and midwifery programmes in Chile currently or plan to offer abortion training, if at all, and whether they will require their students to participate at some level is still unclear.
This study had a number of limitations. Our response rate was low, a common characteristic of web-based surveys and surveys on sensitive topics. ${ }^{35}$ Thus, our findings may suffer from response bias. While this study successfully reached students from secular and religious universities, students from religious universities were somewhat under-represented. According to the Ministry of Education, approximately $35 \%$ of the medical and midwifery student population within our seven university recruitment sites are at religiously-affiliated universities, whereas less than one quarter $(23 \%)$ of our responding sample came from religiously-affiliated universities. ${ }^{14}$ Thus, the views presented here are likely more supportive of abortion than medical and midwifery students across the country. The lack of statistically significant differences between participant characteristics and rates of survey completion mitigates some of these concerns. Furthermore, the significant associations between variables should not be affected by non-response bias. Nonetheless, students' attitudes about abortion provision are similar to those reported among obstetricians and gynaecologists in Argentina, ${ }^{36}$ a country that also has very restrictive abortion laws. Another study limitation lies in that we did not ask students under which of the three legal grounds they would consider providing abortion services or whether they were aware about the change in the law or the circumstances under which abortion was recently decriminalised. Just 1 year after legal implementation, nearly half $(47 \%)$ of OB/GYN providers working in public hospitals are claiming conscientious objection status to refuse to provide abortion specifically by reason (woman's health in danger, pregnancy result of rape or fetal malformation); reasons that were not explored in this study. ${ }^{37}$

\section{CONCLUSIONS}

This is the first known study to assess Chilean medical and midwifery students' willingness to provide abortion services following legal reform. Students are interested in receiving training and providing abortion care to their patients and believe their university should provide this training. Ensuring that high-quality training in abortion care is integrated within medical and midwifery programmes will be critical to ensuring that people receive timely, non-judgemental and quality abortion care.

Contributors MAB and LC conceived and designed the study and obtained funding. AR, CFB and SVC participated in study planning, site recruitment, review of data collection instruments and conducted data collection. MAB conducted all data analyses and drafted the manuscript. DG helped to obtain funding. All authors revised and approved the final manuscript.

Funding This work was supported by a grant from the University of California, San Francisco (UCSF), National Center of Excellence in Women's Health and an anonymous foundation.

Competing interests None declared.

Patient consent for publication Not required. 
Ethics approval The study protocol received ethical approval from the University of Diego Portales, Santiago, Chile.

Provenance and peer review Not commissioned; externally peer reviewed.

Data availability statement Data are available upon reasonable request.

Open access This is an open access article distributed in accordance with the Creative Commons Attribution Non Commercial (CC BY-NC 4.0) license, which permits others to distribute, remix, adapt, build upon this work non-commercially, and license their derivative works on different terms, provided the original work is properly cited, appropriate credit is given, any changes made indicated, and the use is non-commercial. See: http://creativecommons.org/licenses/by-nc/4.0/.

ORCID iD

M Antonia Biggs http://orcid.org/0000-0002-3904-3177

\section{REFERENCES}

1 Casas-Becerra L. Women prosecuted and imprisoned for abortion in Chile. Reprod Health Matters 1997;5:29-36.

2 Casas L, Vivaldi L. Abortion in Chile: the practice under a restrictive regime. Reprod Health Matters 2014;22:70-81.

3 Center for Reproductive Law \& Policy. Women behind bars. New York, NY, 1998.

4 Gonzalez R, Requejo JH, Nien JK, et al. Tackling health inequities in Chile: maternal, newborn, infant, and child mortality between 1990 and 2004. Am J Public Health 2009;99:1220-6.

5 Donoso Siña E. Reducción de la mortalidad materna en Chile de 1990 a 2000. Rev Panam Salud Publica 2004;15:326-30.

6 Ministerio de salud. Ley 21.030: Regla la despenalización de la interrupción voluntaria del embarazo en tres causales 2017.

7 Ministerio de salud. Orientaciones técnicas, acogida y acompañamiento psicosocial en el marco de la Ley 21.030, que despenaliza la interrupcion voluntaria del embarazo en tres causales: Govierno de Chile 2018.

8 Ministerio de salud. IVE: Reporte mensual actualizado al 25 de diciembre de 2018, 2018. Available: https://www.minsal.cl/ivereporte-mensual-actualizado/

9 Rominski SD, Lori J, Nakua E, et al. What makes a likely abortion provider? Evidence from a nationwide survey of final-year students at Ghana's public midwifery training colleges. Contraception 2016;93:226-32.

10 Quintero-Roa EM, Ochoa-Vera ME. [Knowledge and attitudes of medical students on decriminalized induced abortion]. Rev Salud Publica 2015;17:912-24.

11 Geleto A, Markos J. Awareness of female students attending higher educational institutions toward Legalization of safe abortion and associated factors, Harari region, eastern Ethiopia: a cross sectional study. Reprod Health 2015;12:19.

12 Sjöström S, Essén B, Gemzell-Danielsson K, et al. Medical students are afraid to include abortion in their future practices: in-depth interviews in Maharastra, India. BMC Med Educ 2016;16:016-532.

13 Cockrill K, Upadhyay UD, Turan J, et al. The stigma of having an abortion: development of a scale and characteristics of women experiencing abortion stigma. Perspect Sex Reprod Health 2013;45:79-88.

14 Consejo Nacional de Educacion. Matrícula Instituciones/Programas Educación superior, 2018. Available: https://www.cned.cl/indices/ matricula-institucionesprogramas-educacion-superior

15 Harris LF, Halpern J, Prata N, et al. Conscientious objection to abortion provision: why context matters. Glob Public Health 2018;13:556-66.

16 Wheeler SB, Zullig LL, Reeve BB, et al. Attitudes and intentions regarding abortion provision among medical school students in South Africa. Int Perspect Sex Reprod Health 2012;38:154-63.
17 Shotorbani S, Zimmerman FJ, Bell JF, et al. Attitudes and intentions of future health care providers toward abortion provision. Perspect Sex Reprod Health 2004;36:58-63.

18 Harris LF, Awoonor-Williams JK, Gerdts C, et al. Development of a conceptual model and survey instrument to measure conscientious objection to abortion provision. PLoS One 2016;11:e0164368.

19 Thomas RG, Norris AH, Gallo MF. Anti-legal attitude toward abortion among abortion patients in the United States. Contraception 2017;96:357-64.

20 Montero A, Villarroel R. A critical review of conscientious objection and decriminalisation of abortion in Chile. $J$ Med Ethics 2018;10:medethics-2017-104281-83.

21 Marin C, Segovia M. A la medida perfecta de la UC: Minsal cambia protocolo sobre objeción de conciencia en ley de aborto. El Mostrador 2018

22 Michalik A, Zdun-Ryżewska A, Pięta B, et al. Multicenter study on midwifery students' attitudes towards abortion and it's place in their future practice - comparison of respondents at early and late stages of the University education. Nurse Educ Pract 2019;35:42-7.

23 Battistelli MF, Magnusson S, Biggs MA, et al. Expanding the abortion provider workforce: a qualitative study of organizations implementing a new California policy. Perspect Sex Reprod Health 2018;50:33-9.

24 Block A, Dehlendorf C, Biggs MA, et al. Postgraduate experiences with an advanced reproductive health and abortion training and leadership program. Family medicine 2017;49:706-13.

25 Rubio G. Jorge Villarreal international Plenary: legal abortion for the first time in 28 years: translating law into high-quality services. Seattle, WA: National Abortion Federation, 2018.

26 Corporación Humanas. Realidad del aborto en Chile: Revisión de información estadística, 2018. Available: http://www.humanas.cl/?p= 17933

27 Debbink MLP, Hassinger JA, Martin LA, et al. Experiences with the providers share workshop method: abortion worker support and research in tandem. Qual Health Res 2016;26:1823-37.

28 Bennett CL, McDonald DA, Finch A, et al. North Carolina medical student views on abortion. N C Med J 2018;79:14-19.

29. Jozkowski KN, Crawford BL, Hunt ME. Complexity in attitudes toward abortion access: results from two studies. Sexuality Research and Social Policy 2018;15:464-82.

30 Yam EA, Dries-Daffner I, García SG. Abortion opinion research in Latin America and the Caribbean: a review of the literature. Stud Fam Plann 2006;37:225-40.

31 Steinauer JE, Turk JK, Preskill F, et al. Impact of partial participation in integrated family planning training on medical knowledge, patient communication and professionalism. Contraception 2014;89:278-85.

32 Steinauer JE, Hawkins M, Turk JK, et al. Opting out of abortion training: benefits of partial participation in a dedicated family planning rotation for ob-gyn residents. Contraception 2013;87:88-92.

33 O'Donnell J, Holt K, Nobel K, et al. Evaluation of a training for health and social service providers on abortion Referral-Making. Matern Child Health J 2018;22:1369-76.

34 Wallace RR, Goodman S, Freedman LR, et al. Counseling women with early pregnancy failure: utilizing evidence, preserving preference. Patient Educ Couns 2010;81:454-61.

35 Edwards PJ, Roberts I, Clarke MJ, et al. Methods to increase response to postal and electronic questionnaires. Cochrane Database of Systematic Reviews 2009;18.

36 Gogna M, Romero M, Ramos S, et al. Abortion in a restrictive legal context: the views of obstetrician-gynaecologists in Buenos Aires, Argentina. Reprod Health Matters 2002;10:128-37.

37 Corporacion Humanas. Implementación de la Ley № 21.030 que regula la despenalización de la interrupción voluntaria del embarazo en tres causales: Objeción de conciencia en hospitales públicos y en instituciones y su impacto en el ejercicio de derechos de las mujeres y niñas 2018. 